\title{
I.UMIBUNG
}

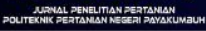

\section{APLIKASI BIOFERTILIZER MENGANDUNG BAKTERI Azotobacter dan Pseudomonas fluorescens Indigenous DENGAN BERBAGAI BAHAN SUBSITUSI TERHADAP PRODUKSI PADI METODE SRI}

\author{
Nelson Elita ${ }^{1}$, Setya Dharma ${ }^{1}$ dan Harmailis ${ }^{2}$ \\ ${ }^{1}$ Program Studi Budidaya Tanaman Pangan Politeknik Pertanian Negeri Payakumbuh \\ ${ }^{2}$ Program Studi Tata Air Pertanian Politeknik Pertanian Negeri Payakumbuh \\ J1. Raya Negara Km. 7 Tanjung Pati, 26271, Payakumbuh \\ Korespondensi: nelsonelita2014@gmail.com
}

\author{
Diterima : 27 Agustus 2020 \\ Disetujui : 29 Agustus 2020 \\ Diterbitkan : 31 Agustus 2020
}

\begin{abstract}
ABSTRAK
Bahan organik dan aktivitas biotik mikroba berfungsi menciptakan dan menstabilkan struktur tanah. Penggunaan pupuk organik yang mengandung mikroba pada tanah sawah meningkatkan pertumbuhan tanaman dan kualitas tanah dengan mempengaruhi aktivitas dan populasi mikroba. Tujuan penelitian adalah mengetahui jumlah koloni bakteri dari Biofertilizer setelah inkubasi 7 hari dan memperoleh media kompos organik dengan bahan subsitusi yang tepat bagi pupuk Biofertilizer mengandung bakteri Azotobacter dan Pseudomonas fluorescents dapat meningkatkan produksi padi metode SRI. Penelitian menggunakan Rancangan Acak Kelompok dengan 7 perlakuan dan 3 ulangan. Perlakuan yang digunakan yaitu: (1). B0 : Kompos, (2). B1 : Kompos + gula pasir + bakteri (Azotobacter dan P. flourescents), (3). B2 : Kompos + Molase + Bakteri (Azotobacter dan $P$ flourescents). (4). B3 : Kompos + CMC + bakteri (Azotobacter dan P flourescents), (5). B4 : Kompos + Arginin + bakteri (Azotobacter dan P. flourescents). (6). B5 : Kompos + Gula pasir + CMC + bakteri (Azotobacter dan P. flourescents). (7). B6 : Kompos + Molasse + Arginin + bakteri (Azotobacter dan P. flourescents). Hasil penelitian menunjukkan bahwa pada pengamatan jumlah koloni bakteri tertinggi setelah inkubai 7 hari terdapat pada media B2 (Kompos + Molase + Bakteri (Azotobacter dan $P$ flourescents), aplikasi pada percobaan pot diperoleh perlakuan B3 (Kompos $+\mathrm{CMC}+$ bakteri (Azotobacter dan $P$ flourescents) meningkatkan pertumbuhan vegetatif dan generatif tanaman padi metode SRI. Kesimpulan jumlah koloni bakteri tertinggi dari biofertizer pada perlakuan B2, setelah aplikasi pada percobaan pot tidak menjamin memberikan hasil terbaik. Hasil terbaik diperoleh perlakuan B3 meningkatkan pertumbuhan vegetatif dan generatif tanaman pada budiaya padi metode SRI.
\end{abstract}

Kata Kunci : Biofertilizer, Azotobacter, Pseudomonas fluorescents, SRI

\section{ABSTRACT}

Organic matter and microbial biotic activities create and stabilize soil structure. The use of organic fertilizers containing microbes in paddy soil increases plant growth and soil quality by affecting microbial activity and population. The research objective was to obtain the right type of biofertilizer to increase rice production using the SRI method. The study used a 


\section{I.UMIBUNG}

randomized block design with 7 treatments and 3 replications. The treatments used were: (1). B0: Compost, (2). B1: Compost + sugar + bacteria (Azotobacter and P. fluorescens), (3). B2: Compost + Molasses + Bacteria (Azotobacter and P fluorescens). (4). B3: Compost + CMC + bacteria (Azotobacter and P fluorescens), (5). B4: Compost + Arginine + bacteria (Azotobacter and P. fluorescens). (6). B5: Compost + Sugar + CMC + bacteria (Azotobacter and P. fluorescens). (7). B6: Compost + Molasse + Arginine + bacteria (Azotobacter and P. fluorescens). The results showed that the observation of the highest number of bacterial colonies after 7 days of incubation was found in B2 media (Compost + Molasses + Bacteria (Azotobacter and $P$ fluorescens), the application in the pot experiment obtained B3 treatment (Compost $+C M C+$ bacteria (Azotobacter and $P$ fluorescens). Increase vegetative and generative growth of rice plants using SRI method. Conclusion, the highest number of bacterial colonies from Biofertizer in B2 treatment.Application in pot experiments the best results obtained by $B 3$ treatment increased vegetative and generative growth of plants on SRI method rice cultivation.

\section{Keywords: Biofertilizer, Azotobacter, Pseudomonas fluorescens, SRI}

\section{PENDAHULUAN}

Saat ini, metode SRI sudah banyak dilakukan dengan berbagai kombinasi teknologi produksi (Uphoff et al. 2015). Metode SRI mengubah pengelolaan tanaman budidaya padi dengan jarak tanam lebar, bibit muda, jumlah bibit per titik tanam sedikit, penggunaan bahan organik yang banyak dan mengurangi pemupukan anorganik sehingga alokasi input lebih efisien, khususnya air, benih dan pupuk, namun jumlah tenaga kerja bertambah karena sistem kering gulma cepat tumbuh (Berkhout et al. 2015).

Budidaya padi metode SRI dengan sistem aerob mempengaruhi terhadap kualitas beras yang dihasilkan yang membuat rasa nasi lebih tahan basi serta enak dan padat. Pengurangan kebutuhan air selama fase vegetatif, yang berarti sistem aerob selama fase vegetatif meningkatkan jumlah anakan sehingga dapat meningkatkan produksi tanaman (Gathome-Hardy et al. 2016).

SRI menggunakan sistem aerobik selama fase vegetatif, memungkinkan mikroorganisme perombak hidup dan aktif, serta ketersediannya melimpah. Uphoff (2003) menyatakan kondisi aerobik mendukung mikroba tanah dan keanekaragamannya melimpah dilahan melalui eksudat akar.

Sawah intensifikasi selama ini didominasi pupuk buatan yang tinggi terutama $\mathrm{N}$ dan P. Nitrogen sebagai unsur hara makro esesial, memiliki peranan penting dalam meningkatkan produksi padi. Kekahatan ketersediaan $\mathrm{N}$ dapat menjadi faktor pembatas dalam peningkatan produksi padi. 


\section{I.UMIBUNG}

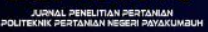

Masalah unsur N pada lahan basah ketersediaannya singkat, mudah terlarut dalam air, terbawa perkolasi, aliran permukaan dan mudah menguap. Efisiensi serapan pupuk N (Urea) oleh tanaman padi sawah relatif rendah berkisar 30-50\%, hal ini menambah besarnya biaya produksi ditanggung petani (P. Kale, A., \& N. Gawade, S. 2016). Penggunaan pupuk kimia secara intensif pada lahan pertanian jangka panjang menyebabkan penurunan kadar organik tanah, struktur tanah rusak dan terjadi pencemaran lingkungan.

Solusi efektif dan efisien yaitu pendekatan secara biologi dengan memanfaatkan kelompok rhizobakteria. Keberadaan rhizobakteria indigenous sangat beragam didalam tanah. Hal ini dipengaruhi faktor biotik dan abiotik yang ada di dalam tanah.

Rhizobakteria berinteraksi sistem perakaran tanaman, baik secara langsung maupun tidak langsung berpengaruh terhadap pertumbuhan tanaman. Jenis rhizobakteria meningkatkan ketersediaan unsur hara khusus $\mathrm{N}$ adalah jenis penambat $\mathrm{N}$ asli setempat (indigenous) (Kumar et al., 2018) . Rhizobakteria mampu mengikat nitrogen dari udara, baik secara simbiotik maupun nonsimbiotik. Beberapa jenis rhizobakteria dapat berfungsi sebagai Rhizobakteria Pemacu Pertumbuhan Tanaman (RPPT), yang biasa ditemukan pada tanaman gramineae seperti padi. Mekanisme PGPR termasuk mengatur keseimbangan hormonal dan nutrisi, mendorong resistensi terhadap patogen tanaman, dan nutrisi pelarutan untuk penyerapan yang mudah oleh tanaman (Gurikar, C., Naik, M. K., \& Sreenivasa, M. Y. 2016).

Hasil penelitian Elita, et al $(2012,2018)$ telah ditemukan Pseudomonas fluorescens indigenous. dan Azotobacter indigenous pada budidaya padi Metode SRI. Karakteristik dan sifat Pseudomonas fluorescens dan Azotobacter indigenous ini lebih efektif, adaptif dan efisien perkembangan dan pertumbuhannya karena diberdayakan pada ekosistem alamiahnya.

Berdasarkan uraian diatas bahwa pemanfaatan Biofertilizer yang mengandung bakteri Azotobacter dan Pseudomonas fluorescens indigenous yang diformulasi dengan kompos organik yang ditambah dengan berbagai bahan subsitusi yang diaplikasi pada padi metode SRI diyakini dapat meningkatkan produksi padi sehingga dapat menekan pemakaian pupuk $\mathrm{N}$ dan $\mathrm{P}$ anorganik dan terjaga kelestarian lingkungan serta biaya usaha tani jadi rendah. Tujuan penelitian :

Memperoleh jenis pupuk Biofertilizer yang tepat dapat meningkatkan produksi padi metode SRI. 


\section{I.UMIBUNG}

ISSN 1412-1948

\section{METODOLOGI PENELITIAN}

Penelitian dilaksanakan mulai bulan Mei sampai September 2019. Tempat penelitian laboratorium Biologi dan di rumah plastik Politeknik Pertanian Negeri Payakumbuh.

Bahan dan Alat : Bahan yang digunakan adalah bakteri Azotobacter dan Pseudomonas fluorescens indigenous, kompos, molasse, CMC, Arginin, gula pasir, media agar, benih padi vareitas Junjung dan pupuk Urea, SP36 dan KCL, tanah sawah. Alat yang digunakan adalah cawan petri, pinset, jarum ose, ember, cangkul, gembor, meteran, timbangan.

Metode Penelitian : Penelitian menggunakam Rancangan Acak Lengkap dengan 7 perlakuan dan 3 ulangan. Dosis kompos yang digunakan 3 ton/ha (27 gram/ember) Perlakuan jenis Biofertilizer yang sudah diformulasi dengan kompos dan di campur dengan bahan subsitusi lain yaitu :

B0 : Kompos

B1 : Kompos + gula pasir + bakteri (Azotobacter dan P. fluorescens)

B2 : Kompos + Molase + Bakteri (Azotobacter dan P fluorescens)

B3 : Kompos + CMC + bakteri (Azotobacter dan P fluorescens)

B4 : Kompos + Arginin + bakteri (Azotobacter dan P. fluorescens)

B5 : Kompos + Gula pasir + CMC + bakteri (Azotobacter dan P. fluorescens)

B6 : Kompos + Molasse + Arginin + bakteri (Azotobacter dan P. fluorescens)

Prosedur Kerja : Penelitian dimulai dengan membuat kompos dari bahan kotoran sapi dan jerami padi dan bioaktivator Trichoderma harzianum dengan formula $(60 \%=6 \mathrm{~kg})$ kotoran sapi : $(30 \%=3 \mathrm{~kg})$ jerami padi : $(10 \%=1 \mathrm{~kg})$ Trichoderma harzianum. . Pembalikan dilakukan dengan cangkul setiap 3 hari sekali. Dilakukan fermentasi selama 28 hari.

Penelitian laboratorium : kompos diayak dengan menggunakan ayakan ukuran 10 mesh masing-masing 100 gram untuk setiap perlakuan. Perlakuan $\mathrm{B}_{0}$ kompos saja, $\mathrm{B}_{1}, \mathrm{~B}_{2}$, $\mathrm{B}_{3}, \mathrm{~B}_{4} \mathrm{~B}_{5}$ dan $\mathrm{B}_{6}$ dicampur dengan bahan subsitusi masing-masing $\pm 1 \%$ dari total berat kompos sesuai dengan perlakuan. Selanjutnya ditambahkan sebanyak @ $5 \mathrm{~mL}$ bakteri Azotobacter sp dan Pseudomonas fluorescens yang sudah di perbanyak massal dengan total populasi bakteri $10^{6} \mathrm{sel} / \mathrm{mL}$ yang dinamakan Biofertilizer. Masing-masing Biofertilizer diinkubasi selama 7 hari.

Perhitungan jumlah koloni bakteri : Setiap Biofertilizer diambil 1 gram dilakukan pengenceran sampai $10^{-6}$ diisolasi ke setiap cawan petri yang berisi media PDA sebanyak 7 perlakuan dan ulangan 3 kali dan inkubasi selama 24 jam, dihitung jumlah koloni bakteri 


\section{I.UMIBUNG}

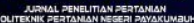

yang tumbuh dalam waktu 24 jam. Jumlah populasi bakteri dihitung dengan membagi jumlah koloni bakteri dengan faktor pengenceran dikali volume sample.

Total populasi bakteri $=\underline{\text { Jumlah koloni }}$

faktor pengenceran $x$ volume sampel

(Badan Standar Nasional, 1992; Cappuccino and Sherman, 2014).

Penelitian di rumah plastik : benih dikecambahkan di seedbed sampai umur 12 hst. Siapkan media tanah sawah dalam ember sebanyak 21 ember. Ukuran ember diameter $35 \mathrm{~cm}$. Volume tanah sawah dalam $10 \mathrm{~kg} / \mathrm{ember}$. Bibit ditanam 1 batang per ember. Pupuk Biofertilizer diaplikasikan sejumlah 27 gram/ember.

Pengamatan yang dilakukan adalah: Penelitian laboratorium jumlah koloni bakteri Azotobacter sp dan Pseudomonas fluorescens, Penelitian rumah Plastik :(1) Tinggi Tanaman (cm),(2) Jumlah anakan, (3) Jumlah malai/ rumpun. (4) Jumlah butir/malai, (5) Berat 1000 biji, (6) Produksi per rumpun.

Untuk menguji pengaruh perlakuan terhadap respon yang diamati dilakukan analisis sidik ragam dengan menggunakan Statistical Analysis System (SAS) program.Selanjutnya dilakukan uji wilayah berganda Duncan New Multiple Range Test (DNMRT) untuk melihat perbedaan perlakuan pada taraf $5 \%$.

\section{HASIL DAN PEMBAHASAN}

\section{Biofertilizer dengan berbagai bahan subsitusi}

Biofertilizer yang diaplikasikan pada budidaya padi metode SRI merupakan campuran bahan kompos, berbagai bahan subsitusi dan bakteri Azotobacter dan P.fluorescens. Populasi bakteri Azotobacter dan P.fluorescens yang tumbuh pada media PDA seperti disajikan pada Gambar 1.

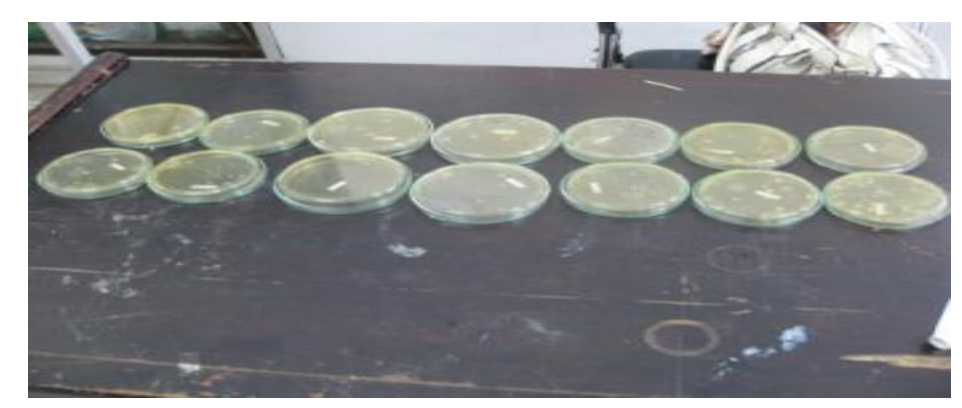

Gambar 1. Jumlah koloni bakteri Azotobacter dan P. fluorescens setelah inkubasi selama selama 24 jam. 


\section{I.UMBUNA}

Hasil pengamatan jumlah koloni bakteri Azotobacter sebagai RPPT indigenous dan Pseudomonas fluorescens indigenous setelah 24 jam dianalisa secara statistik disajikan pada Tabel 1.

Tabel 1. Jumlah koloni bakteri formulasi isolate Azotobacter sebagai RPPT indigenous dan Pseudomonas fluorescens indigenous

\begin{tabular}{cc}
\hline Media Mikroba & Jumlah Koloni Bakteri (CPU/mL) \\
\hline $\mathrm{B}_{2}$ & $156.33 \times 10^{6 \mathrm{a}}$ \\
$\mathrm{B}_{6}$ & $133.33 \times 10^{6 \mathrm{~b}}$ \\
$\mathrm{~B}_{5}$ & $128.00 \times 10^{6 \mathrm{~b}}$ \\
$\mathrm{~B}_{1}$ & $83.67 \times 10^{6 \mathrm{c}}$ \\
$\mathrm{B}_{3}$ & $78.33 \times 10^{6 \mathrm{c}}$ \\
$\mathrm{B}_{4}$ & $68.67 \times 10^{6 \mathrm{~d}}$ \\
$\mathrm{~B}_{0}$ & $1.67 \times 10^{6 \mathrm{e}}$ \\
\hline
\end{tabular}

Angka-angka pada kolom yang diikuti huruf kecil yang sama berbeda tidak nyata pada taraf nyata $5 \%$ menurut DMRT.

Pada Tabel 1. Dapat dilihat bahwa jumlah koloni bakteri Azotobacter sebagai RPPT dan Pseudomonas fluorescens indigenous tertinggi terdapat pada perlakuan $\mathrm{B}_{2}$ (Kompos + Molase + bakteri $(\mathrm{A}+\mathrm{P})$, hal ini menunjukkan bahwa perlakuan kompos dengan molasse mampu menghasilkan pertumbuhan bakteri berkembang dengan cepat.

Molase yang diberikan dalam bentuk cairan pada media sehingga bakteri memperoleh sumber energi dengan mudah. Molase diperlukan oleh bakteri sebagai sumber gula dan energi sehingga pertumbuhan koloni bakteri lebih cepat dengan tersedianya makanan. Media pertumbuhan mikroorganisme adalah suatu bahan yang terdiri dari campuran zat-zat makanan atau nutrisi yang diperlukan oleh mikroorganisme untuk pertumbuhannya (Tanaka et al., 2014). Mikroorganisme memanfaatkan nutrisi di dalam media berupa molekul-molekul kecil yang dirakit untuk menyusun komponen sel. (Elpawati et al., 2016).

Pada perlakuan $\mathrm{B}_{0}$ masih terdapat pertumbuhan jumlah koloni bakteri, kemungkinan terbawa dari kompos, kompos tidak dilakukan sterilisasi karena proses kompos menggunakan jamur Trichoderma harzianum.

\section{Aplikasi Biofertilizer pada percobaan Pot}

Hasil pengamatan dari uji berbagai jenis bahan pembawa media Biofertilizer yang mengandung bakteri Azotobacter dan P. fluorescens indigenous setelah diuji secara statistik untuk pengamatan vegetatif disajikan pada Tabel 2. 


\section{I.UMIBUNG}

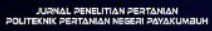

Tabel 2. Pengamatan vegetatif dari uji berbagai jenis bahan pembawa media Biofertilizer yang mengandung bakteri Azotobacter dan P. fluorescens.

\begin{tabular}{|c|c|c|c|c|c|}
\hline \multicolumn{2}{|r|}{ Perlakuan } & \multicolumn{2}{|c|}{$\begin{array}{c}\text { Tinggi } \\
\text { Tanaman }(\mathrm{cm})\end{array}$} & \multicolumn{2}{|c|}{$\begin{array}{l}\text { Jumlah Anakan } \\
\text { (anakan) }\end{array}$} \\
\hline $\mathrm{B}_{0}:$ & Kompos & 122,00 & d & 25,67 & $\mathrm{c}$ \\
\hline $\mathrm{B}_{1}:$ & $\begin{array}{l}\text { Kompos + gula pasir + bakteri (Azotobacter } \\
\text { dan P. fluorescens) }\end{array}$ & 124,67 & d & 28,33 & $\mathrm{bc}$ \\
\hline $\mathrm{B}_{2}:$ & $\begin{array}{l}\text { Kompos + Molase }+ \text { Bakteri (Azotobacter } \\
\text { dan Pfluorescens) }\end{array}$ & 135,00 & ab & 29,00 & $\mathrm{bc}$ \\
\hline $\mathrm{B}_{3}:$ & $\begin{array}{l}\text { Kompos + CMC + bakteri (Azotobacter dan } \\
\text { P fluorescens) }\end{array}$ & 137,33 & $\mathrm{a}$ & 36,00 & $\mathrm{a}$ \\
\hline $\mathrm{B}_{4}:$ & $\begin{array}{l}\text { Kompos }+ \text { Arginin }+ \text { bakteri (Azotobacter } \\
\text { dan P. fluorescens) }\end{array}$ & 124,33 & $\mathrm{c}$ & 27,33 & c \\
\hline $\mathrm{B}_{5}:$ & $\begin{array}{l}\text { Kompos + Gula pasir + CMC + bakteri } \\
\text { (Azotobacter dan P.fluorescens) }\end{array}$ & 132,00 & $\mathrm{~b}$ & 32,67 & $\mathrm{ab}$ \\
\hline $\mathrm{B}_{6}:$ & $\begin{array}{l}\text { Kompos }+ \text { Molasse }+ \text { Arginin }+ \text { bakteri } \\
\text { (Azotobacter dan P. fluorescens })\end{array}$ & 123,00 & $\mathrm{~cd}$ & 30,33 & $\mathrm{~b}$ \\
\hline
\end{tabular}

Angka-angka pada kolom yang diikuti huruf kecil yang sama berbeda tidak nyata pada taraf nyata $5 \%$ menurut DMRT.

Pada Tabel 2 dapat dilihat tinggi tanaman dan jumlah anakan tertinggi terdapat pada perlakuan $\mathrm{B}_{3}$ dan berbeda nyata dengan perlakuan lainnya. Pada perlakuan $\mathrm{B}_{3}$ dengan bahan pembawa CMC, dapat meningkatkan populasi dan kemampuan bertahan hidup bakteri Azotobacter sp dan P. fluorescens setelah berada didalam tanah. Keberadaan bakteri Azotobacter sp dan $P$. fluorescens pada perlakuan $\mathrm{B}_{3}$ mampu menyediakan unsur hara yang dibutuhkan tanaman padi. Kondisi ini mempengaruhi terhadap peningkatan pertumbuhan tinggi tanaman dan jumlah anakan tanaman padi..

Pemberian kompos saja memberikan pengaruh tinggi tanaman dan jumlah anakan paling rendah. Kompos yang terbuat dari bahan jerami dan kotoran sapi dengan dekomposer Trichoderma harzianum belum cukup menyediakan unsur hara sehingga pertumbuhan tinggi tanaman dan jumlah anakan paling rendah dibandingkan dengan perlakuan lainnya. Tampaknya jumlah dan banyaknya jenis mikroba sangat berperan penyediaan unsur hara yang dapat mempengaruhi pertumbuhan tanaman.

Hasil penelitian menunjukkan bahwa peningkatan jumlah anakan pada perlakuan $\mathrm{B}_{3}$ (Kompos + CMC + bakteri Azotobacter dan $P$ fluorescens) sebanyak 40,24 \% dibandingkan dengan kompos saja. Lebih besarnya jumlah anakan pada perlakuan B3 menunjukkan peran bakteri Azotobacter dan P.fluorescens dalam menyediakan nutrisi sudah terlihat pada pertumbuhan vegetatif. 


\section{I.UMIJUNG}

Pada perlakuan $\mathrm{B}_{3}$ kompos ditambah dengan bahan subsitusi CMC menunjukkan populasi bakteri Azotobacter dan P. fluorescens dapat menyediakan unsur hara dan kemampuan bertahan hidupnya lebih tinggi. CMC merupakan merupakan eter polimer selulosa linear dan berupa senyawa anion, yang bersifat biodegradable, tidak berwarna, tidak berbau, tidak beracun, butiran atau bubuk yang larut dalam air namun tidak larut dalam larutan organik, memiliki rentang $\mathrm{pH}$ sebesar 6.5 sampai 8.0, stabil pada rentang $\mathrm{pH} 2-10$, bereaksi dengan garam logam berat membentuk film yang tidak larut dalam air, transparan, serta tidak bereaksi dengan senyawa organik (Deviwings, 2008).

Carboxymethylcellulose (CMC) adalah eter asam karboksilat turunan selulosa yang berwarna putih, tidak berbau, padat, digunakan sebagai bahan penstabil (Fennema, 1996). Carboxymethylcellulose (CMC) dibuat dari reaksi sederhana yaitu pulp kayu ditambah dengan $\mathrm{NaOH}$ kemudian direaksikan dengan $\mathrm{Na}$ monokhlor asetat atau dengan asam monoklor asetat (Tranggono, 1990).

Pemupukan dengan bahan organik dapat memperbaiki kondisi fisik tanah menjadi lebih baik . Kondisi pengairan SRI yang menghindari kondisi tanah hipoksia dengan tidak menggenangi selama tahap vegetatif, akan meningkatkan efisiensi sistem akar tanaman padi yang ditanam dengan metode SRI dalam mengambil nutrisi sehingga pertumbuhan akar menjadi kuat dan besar. Hal ini mempengaruhi pertumbuhan anakan dan anakan produktif menjadi lebih banyak (Thakur et al., 2013).

Pada pengamatan pertumbuhan generatif setelah dianalisa secara statistik disajikan pada Tabel 3.

Pada Tabel 3 dapat dilihat jumlah malai terbanyak terdapat pada perlakuan B3 berbeda tidak nyata dengan perlakuan $\mathrm{B}_{5}$. Biofertilizer pada kedua perlakuan ini disubsitusi dengan CMC. Tampaknya peranan CMC sebagai bahan subsitusi mampu meningkatkan populasi mikroba Azotobacter dan P.fluorescens yang memberikan dampak pada pertambahan jumlah malai dibandingkan dengan kompos saja.

Pada pengamatan jumlah butir/malai pada perlakuan $\mathrm{B}_{3}$ memberikan butir terbanyak yang berbeda nyata dengan perlakuan lain. Jumlah butir menggambar hasil fotosintesa yang mengisi gabah. Pada perlakuan $\mathrm{B}_{3}$ mampu menyediakan nutrisi yang cukup bagi pertumbuhan tanaman padi sehingga tanaman padi dapat melakukan aktivitas fotosintesa dengan baik yang menghasilkan jumlah butir terbanyak. 


\section{I.UMIBUNG}

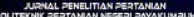

Tabel 3. Pengamatan generatif dari uji berbagai jenis bahan pembawa media Biofertilizer yang mengandung bakteri Pseudomonas fluorescens dan Azotobacter.

\begin{tabular}{|c|c|c|c|c|c|c|}
\hline & Perlakuan & $\begin{array}{l}\text { Jumlah } \\
\text { malai } \\
\text { (malai) }\end{array}$ & $\begin{array}{l}\begin{array}{l}\text { Jumlah } \\
\text { butir/malai } \\
\text { (malai) }\end{array} \\
\end{array}$ & $\begin{array}{l}\text { Berat } 1000 \\
\text { biji (gram) }\end{array}$ & $\begin{array}{l}\text { Produksi } \\
\text { /pot } \\
\text { (gram) }\end{array}$ & $\begin{array}{l}\text { Produksi } \\
\text { /ha (ton) }\end{array}$ \\
\hline $\mathrm{B}_{0}:$ & Kompos & $22,00^{\mathrm{c}}$ & $208,67^{\mathrm{e}}$ & $20,13^{\mathrm{e}}$ & $58,62^{\mathrm{g}}$ & $6,51^{\mathrm{e}}$ \\
\hline $\mathrm{B}_{1}:$ & $\begin{array}{l}\text { Kompos }+ \text { gula pasir }+ \\
\text { bakteri (Azotobacter dan } P . \\
\text { fluorescens) }\end{array}$ & $24,67^{\mathrm{c}}$ & $235,67^{d}$ & $21,47^{\mathrm{d}}$ & $61,40^{\mathrm{f}}$ & $7,67^{\mathrm{d}}$ \\
\hline $\mathrm{B}_{2}:$ & $\begin{array}{l}\text { Kompos + Molase + Bakteri } \\
\text { (Azotobacter dan } P \\
\text { fluorescens) }\end{array}$ & $26,33^{c}$ & $252,67^{d}$ & $21,54^{\mathrm{d}}$ & $69,03^{\mathrm{e}}$ & $7,87^{\mathrm{d}}$ \\
\hline $\mathrm{B}_{3}$ : & $\begin{array}{l}\text { Kompos + CMC + bakteri } \\
\text { (Azotobacter dan } P \\
\text { fluorescens) }\end{array}$ & $35,00^{\mathrm{a}}$ & $299,33^{a}$ & $23,61^{\mathrm{a}}$ & $86,49^{\mathrm{a}}$ & $9,61^{\mathrm{a}}$ \\
\hline $\mathrm{B}_{4}$ : & $\begin{array}{l}\text { Kompos }+ \text { Arginin }+ \text { bakteri } \\
\text { (Azotobacter dan } P . \\
\text { fluorescens) }\end{array}$ & $23,33^{c}$ & $232,33^{c}$ & $21,25^{\mathrm{cd}}$ & $70,83^{d}$ & $6,82^{\mathrm{cd}}$ \\
\hline $\mathrm{B}_{5}:$ & $\begin{array}{l}\text { Kompos + Gula pasir }+ \\
\text { CMC + bakteri (Azotobacter } \\
\text { dan P. fluorescens) }\end{array}$ & $31,33^{a b}$ & $290,67^{b}$ & $22,88^{b}$ & $79,93^{b}$ & $8,88^{b}$ \\
\hline $\mathrm{B}_{6}:$ & $\begin{array}{l}\text { Kompos }+ \\
\text { Arginin } \\
\begin{array}{l}\text { Azotobacter } \\
\text { fluorescens) }\end{array}\end{array}$ & $28,33^{b}$ & $256,00^{\mathrm{c}}$ & $22,11^{\mathrm{c}}$ & $72,98^{\mathrm{c}}$ & $8,11^{\mathrm{c}}$ \\
\hline
\end{tabular}

Angka-angka pada kolom yang diikuti huruf kecil yang sama berbeda tidak nyata pada taraf nyata $5 \%$ menurut DNMRT.

Pada pengamatan berat 1000 biji perlakuan $\mathrm{B}_{3}$ menghasilkan berat tertinggi berbeda nyata dengan perlakuan lain, pada perlakuan $\mathrm{B}_{5}$ memberikan berat 1000 biji yang tinggi setelah perlakuan $\mathrm{B}_{3}$. Perlakuan $\mathrm{B}_{2}$ dan $\mathrm{B}_{4}$ tidak berbeda nyata, hal ini menunjukkan bahwa fenomena kedua perlakuan tersebut hampir sama, sehingga kemampuan bakteri dalam menyediakan nutrisi hampir sama.

Pada pengamatan produksi per pot perlakuan $\mathrm{B}_{3}$ menunjukkan produksi tertinggi yang berbeda nyata dengan perlakuan lain. Demikian juga setelah dikonversi ke hektar perlakuan $\mathrm{B}_{3}$ memberikan hasil tertinggi.

Dihubungkan dengan pengamatan vegetatif (Tabel 1) memperlihatkan bahwa perlakuan $\mathrm{B}_{3}$ memberikan hasil terbaik, yang berpengaruh pada pengamatan generatif. Perlakuan $\mathrm{B}_{3}$ dengan subsitusi CMC bakteri Azotobacter dan. P.fluorescens indigenous mampu bertahan hidup dengan baik sehingga dapat menyediakan nutrisi pada tanaman padi sampai pada fase generatif. Subsituasi CMC pada media Biofertilizer memperkuat daya tahan bakteri Azotobacter dan. P.fluorescens indigenous. 


\section{I.UMIBUNG}

ISSN 1412-1948

Shao-hua et al. (2002) melaporkan hasil yang tinggi dalam metode SRI tidak lepas dari perubahan proses fisiologis yang lebih baik yakni meningkatnya kemampuan akar, kandungan gula terlarut, nitrogen non protein, prolin dan bahan kering pada organ vegetatif, persentase partisi asimilat yang disimpan, persentase luas daun yang efektif dan persentase anakan produktif

Namun populasi total mikroba pada budidaya SRI lebih tinggi dibandingkan praktek konvensional, hal ini membuktikan bahwa SRI cenderung meningkatkan populasi mikrob selama periode pertumbuhan. Hal ini berkaitan dengan pengelolaan tanah yang lebih baik dan sistem pengairan yang diterapkan dimana pada SRI tidak mengenangi lahan secara terus menerus. Kondisi sawah yang tidak digenang secara terus menerus menciptakan lingkungan yang aerob sehingga mendukung peningkatan populasi organisme tanah (Anas et al., 2011)

Populasi mikroba didalam tanah sangat dipengaruhi oleh tingkat kepekaan mikroba, kesuburan tanah, kelembaban serta intensitas cahaya. Populasi mikroba tanah tertinggi umumnya berada pada lapisan rizosfer, hal ini karena daerah rizosfer memiliki komponen carbon (C) yang tinggi sehingga dapat digunakan sebagai sumber energi untuk pertumbuhan mikroba tanah (Suliasih dan S.Widawati. 2006). Kajian lebih banyak harus dilakukan untuk mendapatkan pemahaman yang lebih baik dari faktor-faktor yang mempengaruhi dinamika populasi mikrob dalam hubungannya dengan tanaman, tanah, air, dan pengelolaan hara dan faktor lainnya.

\section{KESIMPULAN}

Jumlah koloni bakteri Azotobacter dan P.fluorescens yang ada dalam Biofertilizer setelah diinkubasi selama 7 hari dan diisolasi ke media PDA selama 24 jam diperoleh jumlah poipulasi bakteri terbanyak pada media $\mathrm{B}_{2}$ yaitu Kompos + Molase + Bakteri (Azotobacter dan $P$ flourescens). Aplikasi Biofertilizer yang mengandung bakteri Azotobacter dan $P$. fluorescens dengan bahan subsitusi CMC $\left(\mathrm{B}_{3}\right)$ memberikan hasil terbaik untuk pertumbuhan vegetatif dan generatif padi metode SRI. Jumlah koloni bakteri yang banyak pada media biakan murni tidak menjamin memberikan pengaruh yang baik setelah diaplikasikan pada tanaman padi.

\section{REFERENSI}

Anas, I., O.P. Rupela, T.M. Thiyagarajan and N. Uphoff. 2011. A review of studies on SRI: effects on beneficial organisms in rice soil rhizosphere. Pady and Water J., 9(1): 53-64. 


\section{I.UMIBUNG}

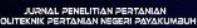

Berkhout, E., Glover, D., \& Kuyvenhoven, A. (2015). On-farm impact of the System of Rice Intensification (SRI): Evidence and knowledge gaps. In Agricultural Systems. https://doi.org/10.1016/j.agsy.2014.10.001.

Deviwings. 2008. CMC. http://deviwings.blogspot.com, Diakses 1 Juli 2011.

Cappuccino, J. G., dan Sherman, N. 2014. Manual Laboratorium Mikrobiologi Edisi 8.Jakarta : EGC

Elita, N, Agustamar, Yulensri. 2012. Eksplorasi dan Reinokulasi Mikroorganisme Pelarut Fospat Indigenous untuk meningkatkan Produksi Padi Metode SRI. Prosiding Seminar Nasional ISBN:978-979-9869-2-8. Pengembangan Agroindustri untuk mendukung Perekonomian Rakyat. 2012.

Elita, N.,Erlinda. Rita, Agustamar. 2018. Proses Penemuan Isolat Azotobacter pada Rhizosfir Tanaman Padi Metode SRI. Surat Pencatatan Ciptaan No. 000113635, tanggal 7 Agustus 2018 dengan permohonan No. EC00201823121

Elpawati, E., Dara, S. D., \& Dasumiati, D. (2016). Optimalisasi Penggunaan Pupuk Kompos dengan Penambahan Effective Microorganism 10 (Em10) pada Produktivitas Tanaman Jagung (Zea mays L.). AL-Kauniyah: Jurnal Biologi. https://doi.org/10.15408/kauniyah.v8i2.2693

Fennema, Owen R. 1996.Food Chemistry Third Edition.Marcel Dekker Inc.New York.

Gathome-Hardy,A, Reddy, D.N., Venkatanarayana,M, Hamsis-White, Barbara, 2016. System of Rice Intensification provides environmental and economic gains but at the expense of social sustainability-A multidisclipnary analysis in India. Agriculture System, Volume 143, March 2016, Pages 159-168.

Gurikar, C., Naik, M. K., \& Sreenivasa, M. Y. (2016). Azotobacter: PGPR activities with special reference to effect of pesticides and biodegradation. In Microbial Inoculants in Sustainable Agricultural Productivity: Vol. 1: Research Perspectives.

Kumar, P., Thakur, S., Dhingra, G. K., Singh, A., Pal, M. K., Harshvardhan, K., Dubey, R. C., \& Maheshwari, D. K. (2018). Inoculation of siderophore producing rhizobacteria and their consortium for growth enhancement of wheat plant. Biocatalysis and Agricultural Biotechnology. https://doi.org/10.1016/j.bcab.2018.06.019

P. Kale, A. and N. Gawade, S. 2016. Studies On Nanoparticle Induced Nutrient Use Eficiency Of Fertilizer And Crop Productivity. Green Chemistry \& Technology Letters. 2, 2 (Apr. 2016), 88-92. DOI:https://doi.org/10.18510/gctl.2016.226.

Shao-hua, W., C. Wexcing, J. Dong, Tingho and Z. Yan. 2002. Physiological characteristics and high-yield tecniques with SRI rice. Naanjing Agricultural University. China. http://www sri.cals.cornell.edu/proc1/sri_27.pdf. 


\section{I.UMIBUNC}

Suliasih, SWidawati,. 2006. Augmentasi Bakteri Pelarut Fosfat (BPF) Potensial sebagai Pemacu Pertumbuhan Caysin (Brasica caventis Oed.) di Tanah Marginal. Biodiversitas. ISSN : 1412-033 x Volume 7, Nomor 1 Januari 2006, 10-14 hal.

Tanaka, T., Kawasaki, K., Daimon, S., Kitagawa, W., Yamamoto, K., Tamaki, H., Tanaka, M., Nakatsu, C. H., \& Kamagata, Y. (2014). A hidden pitfall in the preparation of agar media undermines microorganism cultivability. Applied and Environmental Microbiology. https://doi.org/10.1128/AEM.02741-14

Thakur, A.K., S. Rath and K.G. Mandal. 2013. Differential responses of system of rice intensification (SRI) and conventional flooded-rice management methods to applications of nitrogen fertilizer. Plant Soil, 370(1-2): 59-71. doi:10.1007/s11104013-1612-5.

Tranggono, 1990, Bahan Tambahan Pangan (Food Additives), Pusat Antar Universitas Pangan dan Gizi, Universitas Gadjah Mada, Yogyakarta.

Uphoff, Fasuola, Iswandi, Kassam dan Thakur, 2015. Improving the phenotype expression of rice genotypes : Rethinking"Intensification" for production system and selection practices for rice breeding. The Crop Journal,Volume 3,Issue 3, June 2015, Pages 174189.

Uphoff, N. 2003. Initial Report on China National SRI Workshop. 2-3 Maret 2003, Hangzhou. ciifad@ cornell.edu. Diakses pada tanggal 22-5-2005. 